Check for updates

The BMJ

Cite this as: BMJ 2020;371:m4798 http://dx.doi.org/10.1136/bmj.m4798 Published: 11 December 2020

\section{Covid-19: Moving London into tier 3 would be "big mistake," warns leading epidemiologist}

\author{
Rebecca Coombes
}

A leading epidemiologist has urged the government not to put the UK capital into strict tier 3 measures next week, saying the move would be a "big mistake."

Tim Spector, professor of genetic epidemiology at King's College London and creator of the Covid Symptom Study app, ${ }^{1}$ was responding to concerns that rising covid-19 cases in London in recent weeks would see it lose its tier 2 status.

London now has the highest prevalence of coronavirus infection in England, at 191 cases per 100 ooo population, which compares with 153 cases per 100 ooo for England as a whole. Daily cases rose by $37 \%$ during the most recent week recorded, from 1647 cases on 28 November to 2253 cases on 5 December. Government advisers are due to meet on 16 December to review tiering decisions.

Speaking at a Royal Society of Medicine event, Spector said, "This on-off business is a total disaster, and we should avoid it. In London the decrease has stopped and is flat or slightly increased. Most of the cases are in north London at the moment. It would be a big mistake if London goes into tier 3. I think everyone should be coming down a tier and stay somewhere between tier 1 and 2 until April, when we see the vaccine taking effect."

Spector said there was a danger that people would engage in risky behaviour if they thought their freedom was about to be curtailed even further. "Drinking and festivities will happen if people think that in two days' time 'that is it for another six weeks.' It would be madness to do that.

"We need to think about these tier systems. The whole point should be the capacity of the NHS to deal with it locally. At the moment, according to our data, London has plenty of spare capacity [in hospitals]. We know we aren't going to get rid of this virus before the vaccine, so we need to make sure the NHS is under control and that people over the age of 60 are not getting it at bad rates and have some clear criteria."

He said the government should stop treating people like "cattle" to be led and instead give them better information and trust them to do the right thing. "Just having this league table of who is being relegated and promoted and this on-off effect is madness," he added. "We need a much more consistent pattern that we can all relate to. If you tell people the truth and what is going on in your area-these are the figures, this is how full your hospital is-they will behave responsibly. They need to be part of the discussion not treated as if they are cattle."

But Paul Hunter, professor of medicine at the University of East Anglia, said it was likely London would need stricter controls: "If the epidemic is restricted to teenagers then the impact on hospitals in the area won't be that great ... But we know from the past that once coronavirus is prevalent in one age group, it tends to leak into other age groups and ultimately into the age groups that are most vulnerable," he told BBC Radio 4's Today programme on 11 December.

The three worst hit boroughs in London are Havering, Barking and Dagenham, and Waltham Forest. Havering has 380 cases per 100000 population.

1 Mayor S. Covid-19: Researchers launch app to track spread of symptoms in the UK. BM/2020;368:m1263. doi: 10.1136/bmj.m1263 pmid: 32220898

This article is made freely available for use in accordance with BMJ's website terms and conditions for the duration of the covid-19 pandemic or until otherwise determined by BMJ. You may use, download and print the article for any lawful, non-commercial purpose (including text and data mining) provided that all copyright notices and trade marks are retained. 